Canadian

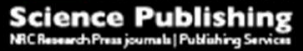

Botany

Botanique

\title{
Cecilanthus polymerus, a novel multiparted flower from the mid-Cretaceous Rocky Point locality, Maryland
}

\begin{tabular}{|r|l|}
\hline Journal: & Botany \\
\hline Manuscript ID & cjb-2016-0039.R1 \\
\hline Danuscript Type: & Article \\
\hline Date Submitted by the Author: & 11-Apr-2016 \\
\hline Complete List of Authors: & $\begin{array}{l}\text { Herendeen, Patrick; Chicago Botanic Garden } \\
\text { Doyle, James; UC Davis } \\
\text { Endress, Peter; University of Zurich } \\
\text { Takahashi, Masamichi; Niigata University }\end{array}$ \\
\hline Keyword: & Cretaceous, Angiosperm, Paleobotany, fossil flowers, Potomac Group \\
\hline & \multicolumn{2}{|l}{} \\
\hline
\end{tabular}

\section{SCHOLARONE ${ }^{\text {m }}$}

Manuscripts 
Cecilanthus polymerus, a novel multiparted flower from the mid-Cretaceous Rocky Point locality, Maryland

Patrick S. Herendeen ${ }^{1}$, James A. Doyle ${ }^{2}$, Peter K. Endress ${ }^{3}$, and Masamichi Takahashi ${ }^{4}$

${ }^{1}$ Chicago Botanic Garden, 1000 Lake Cook Road, Glencoe, Illinois 60022, USA, pherendeen@chicagobotanic.org

${ }^{2}$ Department of Evolution and Ecology, University of California, Davis, CA 95616, USA, jadoyle@ucdavis.edu

${ }^{3}$ Institute of Systematic Botany, University of Zurich, Zollikerstrasse 107, 8008 Zurich, Switzerland, peter.endress@systbot.uzh.ch

${ }^{4}$ Department of Environmental Sciences, Faculty of Sciences, Niigata University, 8050, 2-cho, Ikarashi, Nishi-ku, Niigata, 950-2181, Japan, masamichi@env.sc.niigata-u.ac.jp

Corresponding author: Patrick S. Herendeen (email: pherendeen@chicagobotanic.org) 


\begin{abstract}
A flower from the early Cenomanian of northeastern Maryland, Cecilanthus polymerus gen. et sp. nov., is described using SEM and synchrotron X-ray microtomography. The flower has $>20$ strap-shaped tepals, ca. 50 spathulate stamens with embedded adaxial pollen sacs and possibly H-valvate dehiscence, and ca. 100 more or less plicate carpels. Floral phyllotaxis is whorled, with $>10$ parts per whorl, but slightly irregular. Pollen and ovules are not preserved, but locule shape suggests the carpels are uniovulate. Similar characters occur in extant Magnoliales and the basal ANITA grade, but never in combination. In an attempt to resolve these ambiguities, we performed morphological phylogenetic analyses with the arrangement of extant taxa constrained to trees based primarily on molecular data. With anther dehiscence and ovule number treated as unknown, Cecilanthus has several most parsimonious positions: nested in Nymphaeales, nested in Magnoliales, sister to Laurales, and sister to Chloranthaceae. However, scoring anther dehiscence as $\mathrm{H}$-valvate and ovule number as one increases support for a position in Magnoliales. Cecilanthus demonstrates that the early radiation of angiosperms produced floral morphotypes unlike those in any surviving taxa, and it illustrates the value of characters such as pollen morphology and seed anatomy for phylogenetic placement of floral mesofossils.
\end{abstract}

Keywords: Cretaceous, angiosperm, paleobotany, fossil flowers, phylogeny, Potomac Group

\title{
Résumé
}

Une fleur provenant du Cénomanien inférieur du nord-est du Maryland, Cecilanthus polymerus gen. et sp. nov., est décrite à partir de données de MEB et microtomographie à rayonnement X synchrotron. La fleur porte $>20$ tépales allongés, env. 50 étamines spatulées à sacs polliniques 
adaxiaux enfoncés, peut-être à déhiscence valvaire en H, et env. 100 carpelles plus ou moins pliqués. La phyllotaxie florale est verticillée, avec $>10$ pièces par verticille, mais légèrement irrégulière. Le pollen et les ovules ne sont pas conservés, mais la forme de la loge suggère un carpelle uniovulé. Des caractères similaires se trouvent chez quelques Magnoliales actuelles et dans le grade basal ANITA, mais jamais combinés. Dans le but de résoudre ces ambiguïtés, nous avons conduit des analyses phylogénétiques morphologiques en contraignant les relations entre les taxons actuels à partir d'arbres basés principalement sur des données moléculaires. Lorsque la déhiscence des anthères et le nombre d'ovules sont codés comme inconnus, Cecilanthus a plusieurs positions les plus parcimonieuses: au sein des Nymphaeales, au sein des Magnoliales, comme groupe-frère des Laurales et comme groupe-frère des Chloranthaceae. Cependant, si l'on suppose une déhiscence valvaire des anthères et un nombre d'ovules égal à un, le soutien d'une position au sein des Magnoliales augmente. Cecilanthus démontre que la radiation initiale des Angiospermes a produit des morphotypes floraux différents de tous ceux des taxons survivants, et illustre l'utilité de caractères tels que la morphologie pollinique et l'anatomie des graines pour le placement phylogénétique des mésofossiles floraux.

Mots-clés: Crétacé, Angiosperme, paléobotanique, fleurs fossiles, phylogénie, Groupe Potomac 


\section{Introduction}

The flower described here is the first plant fossil to be reported from a previously undescribed mid-Cretaceous (early Cenomanian) locality at Rocky Point in the Potomac Group of northeastern Maryland. The sediments from this locality contain abundant fossil wood, cuticle, and fern fragments, but relatively few reproductive structures. These include flowers and inflorescence fragments of Mauldinia mirabilis, a relative of Lauraceae, which was first described from the nearby Mauldin Mountain locality (Drinnan et al. 1990; Doyle and Endress 2010). The new flower, here designated Cecilanthus polymerus, is noteworthy for having large numbers of undifferentiated tepals, stamens, and carpels and other features traditionally considered ancestral in angiosperms, but in a combination unlike that seen in any extant group or other known fossil. It therefore extends the spectrum of known angiosperm floral morphology at this time interval, while posing special problems for systematic placement, which we address using a phylogenetic approach.

\section{Materials and Methods}

The fossils described in this paper were isolated from sediments outcropping ca. $10 \mathrm{~m}$ above the beach on a slumped west-facing slope immediately north of Rocky Point on the Elk Neck Peninsula, northeastern Maryland, U.S.A. The Rocky Point locality is ca. $300 \mathrm{~m}$ north of the Mauldin Mountain locality of Drinnan et al. (1990), and ca. $10 \mathrm{~m}$ lower in elevation than the Mauldin Mountain fossil bed, although the Rocky Point exposure is slumped and was therefore originally higher on the hillside. The sediments are assigned to the lowermost part of Zone III in the palynological zonation established for Potomac Group sediments by Brenner (1963) and Doyle and Robbins (1977), which is interpreted to be of earliest Cenomanian age (Doyle and 
Robbins 1977; Drinnan et al. 1990, 1991; Pedersen et al. 1991; Massoni et al. 2015). Thus it is slightly younger than the Albian-Cenomanian boundary, $100.5 \pm 0.4 \mathrm{Ma}$, and considerably older than the middle Cenomanian minimum age for the next well-dated horizon, in the lower Raritan Formation of New Jersey, or 95.5 Ma (Ogg and Hinnov 2012; Massoni et al. 2015).

The fossil flower was isolated from sample PSH119 (collected 16 August, 2000), which was an organic-rich, dark, unconsolidated clay. Bulk matrix samples were dried, disaggregated in water, and then washed through a series of sieves. Residual organic material was then treated with $10 \%$ $\mathrm{HCl}$ followed by $40 \% \mathrm{HF}$ to remove adhering mineral material, washed thoroughly in water, and allowed to dry before sorting. The mesofossil assemblage at Rocky Point consists of charcoalified and lignitized plant material and includes flowers, fruits, seeds, wood, and cuticle fragments.

This new taxon is known from one nearly complete specimen (catalog number PP55896), which is housed in the paleobotanical collections of the Field Museum, Chicago, Illinois, USA, and 15 isolated stamens (PP55897- PP55900). For scanning electron microscopy (SEM) specimens were mounted on aluminum stubs, sputter coated with gold, and studied at the Field Museum using a Leo EVO 60 environmental SEM $(5-10 \mathrm{kV})$. The flower was also imaged for synchrotron X-ray microtomography using similar techniques to those used in previous studies (e.g., Friis et al. 2007, 2009; Takahashi et al. 2008a, 2008b, 2014; von Balthazar et al. 2007; Schönenberger et al. 2012). Scans were made using a 10X objective on the X-ray microscope of 2-BM-B beamline of the Advanced Photon Source (APS) at the U.S. Department of Energy's Argonne National Laboratory. The exposure time at $15 \mathrm{kV}$ was $600 \mathrm{msec}$, and 1,500 projections were acquired 
equi-angularly over $180^{\circ}$. Projection images were post-processed and rearranged into flat- and darkfield-corrected sinogram, and reconstruction was performed on a 64-node cluster. Isotropic voxel dimensions were $0.74 \mu \mathrm{m}$. Three-dimensional microtomographic (micro-CT) images of the fossil flowers were reconstructed with TRI/3DVOL software (64 bit) by Ratoc System Engineering (Tokyo). We show only micro-CT images because internal cracks in the specimen caused excessive charging with SEM (not a problem with micro-CT), and most relevant details are equally visible in the micro-CT renderings.

Phylogenetic relationships of the fossil taxon were evaluated using a molecular scaffold approach (Springer et al. 2001), in which a morphological data matrix of extant and fossil plants is analyzed by parsimony with the arrangement of living taxa fixed to a backbone constraint tree based primarily on molecular data. A total evidence analysis that combined molecular data for living taxa with morphological data for living taxa and fossils might be theoretically preferable, but we have not resolved the practical and theoretical problems of assembling an appropriate set of exemplar species and DNA sequences for the molecular data set. Use of a molecular scaffold assumes that inclusion of fossils would not alter inferred relationships among living taxa, which seems justified by the increasing statistical support for molecular relationships. It is certainly preferable to a purely morphological analysis, since analyses of sequences of three genes and morphology by Doyle and Endress (2000) showed that although analysis of morphology yielded many of the same major angiosperm clades found with molecular data, it gave substantially different relationships among some of them, and in most cases the combined analysis agreed with the molecular results. Some results of a morphological analysis would therefore be highly unparsimonious in terms of molecular data. 
The analytical methods, character list, data set, and backbone trees used follow Doyle and Endress (2014; see also Doyle et al. 2008; Endress and Doyle 2009; Doyle and Endress 2010). The data matrix is provided in the supplementary online material. The extant taxa represent a mixture of single species and clades (usually families, but sometimes subfamilies, as in Magnoliaceae and Monimiaceae, or genera, as in Chloranthaceae), within which ancestral states for variable characters were inferred by parsimony using current data on internal relationships. This assumes that the fossil is not nested within any of these terminal taxa, as appears to be true for previously analyzed Early and mid-Cretaceous fossils, which have character combinations implying that they are stem relatives of terminal taxa (Doyle and Endress 2010, 2014; Doyle 2015). It is unlikely to be nested in large terminal taxa such as Annonaceae or Lauraceae, which have more or less uniform and rather different floral morphologies. The living taxa include only "basal" monocots and eudicots, which assumes that the fossil was not nested among "core" monocots or eudicots. This seems reasonable given that most living members of these clades differ markedly from the fossil in having trimerous, pentamerous, or tetramerous flowers with a low number of perianth parts.

The two backbone trees were designed to represent the range of currently viable hypotheses on relationships among the five mesangiosperm clades. In the D\&E tree, based on the combined analyses of morphological and molecular data by Doyle and Endress (2000) and Endress and Doyle (2009), Chloranthaceae and Ceratophyllum form a clade sister to eudicots, Magnoliidae (sensu Cantino et al. 2007), and monocots; additional more recent molecular evidence for the relationship of Chloranthaceae and Ceratophyllum is reviewed in Doyle and Endress (2014). In 
the $\mathrm{J} / \mathrm{M}$ tree, based on nearly complete plastid genomes (Jansen et al. 2007; Moore et al. 2007; Ruhfel et al. 2014), Chloranthaceae are sister to Magnoliidae and Ceratophyllum is sister to eudicots. Relationships within APG (2009) orders in both backbone trees follow the combined analysis of Doyle and Endress (2000), with modifications based on more recent molecular data (Endress and Doyle 2009). Experiments with other arrangements within Magnoliales and among mesangiosperm clades have given subsets of the most parsimonious positions for the fossil found with the D\&E and $\mathrm{J} / \mathrm{M}$ trees, suggesting that these trees are sufficiently representative.

Based on our observations we were able to score 36 characters of the fossil, out of the 142 characters in the data set, of which 51 can be defined as floral characters. Problems encountered in scoring are discussed in the character list in Appendix A1 and in the Discussion. We consider it most likely that anther dehiscence (76) is H-valvate and ovule number (112) is one per carpel, but this is not known definitively; therefore analyses with these two additional characters scored accordingly were also conducted.

Analyses were performed using the parsimony program PAUP (Swofford 1990), with the arrangement of Recent taxa constrained to the D\&E and $\mathrm{J} / \mathrm{M}$ backbone trees, with random addition of taxa and tree-bisection-reconnection branch swapping. The robustness of the relationships obtained and the relative parsimony of alternative arrangements were evaluated by searching for trees one and two steps longer than the most parsimonious trees and by moving taxa manually with MacClade (Maddison and Maddison 2003). To assess the effects of use of a molecular scaffold on the results, we also conducted unconstrained morphological analyses (i.e., using no backbone tree), with trees rooted on Amborella. Character evolution and characters 
supporting particular relationships were investigated with MacClade. When characters are described as unequivocal synapomorphies, this means that the position of the character state change is unequivocal, not that it occurs only once on the entire tree. Statements that particular positions of the fossil are "x steps worse" mean they are $\mathrm{x}$ steps less parsimonious than the most parsimonious position(s).

\section{Results}

\section{Systematic Description}

Angiospermae

Order and Family. Incertae sedis

Cecilanthus Herendeen, Doyle, Endress et Takahashi, gen. nov.

Type. Cecilanthus polymerus Herendeen, Doyle, Endress et Takahashi, sp. nov.

Etymology. Named for Cecil County, Maryland, in which the fossil site is located; "anthos," Greek for "flower."

Generic Diagnosis. Flower bisexual, with ca. 20 strap-shaped tepals preserved (original number probably 30-40). Perianth phyllotaxis not conclusively established but probably whorled. Stamen and carpel phyllotaxis whorled but somewhat irregular. Stamens ca. 50, broad, scale-like, and spathulate, ending in short connective apex. Anther ca. 2/3 to 3/4 length of stamen. Filament and anther not differentiated, entire stamen smoothly tapering to base. Thecae on ventral (adaxial) surface, four pollen sacs probably embedded. Pollen not preserved. Staminodes absent. Carpels ca. 100, small, short, with ovary locule taking up most of length. Ovules not preserved, but locule shape suggests that carpels are uniovulate. Distal part of carpel pointed and curved toward 
center of gynoecium, lacking distinct style. Receptacle hemispherical to almost 3/4 spherical in gynoecial region.

Cecilanthus polymerus Herendeen, Doyle, Endress et Takahashi, sp. nov.

Holotype. PP55896 (Figs. 1, 3, 4).

Type Locality. Rocky Point locality, north of Rocky Point on the Elk Neck Peninsula, Cecil

County, Maryland, U.S.A. (39²9'23.80"N, 7559'37.14"W).

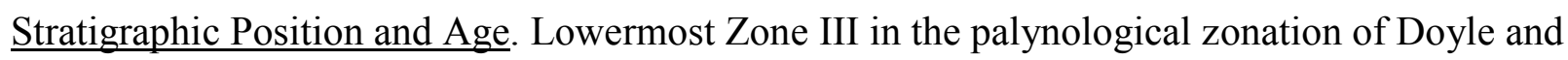
Robbins (1977), of presumed earliest Cenomanian age (Doyle and Robbins 1977; Drinnan et al. 1990, 1991; Pedersen et al. 1991; Massoni et al. 2015).

Etymology. Latinized Greek for "consisting of many parts."

Species Diagnosis. Same as for genus with the following additions. Preanthetic flower $3.2 \mathrm{~mm}$ tall, $2.3 \mathrm{~mm}$ in maximum width; pedicel $1 \mathrm{~mm}$ wide at base, $1.6 \mathrm{~mm}$ wide below tepals.

Detailed Description and Remarks. The single nearly complete fossil flower is well preserved, with most of the organs still attached (Fig. 1A-I). This specimen is $3.2 \mathrm{~mm}$ tall and $2.3 \mathrm{~mm}$ in maximum width. The pedicel is $1 \mathrm{~mm}$ wide at the base and $1.6 \mathrm{~mm}$ wide just below the tepals. The specimen has ca. 20 tepals, which are strap-shaped, $1.8 \mathrm{~mm}$ long and $0.36-0.44 \mathrm{~mm}$ in maximum width; tepals are much longer than the stamens (Fig. 1D-F, D-I). Tepals are completely missing on one side. From the shape of the floral base and the presence of bases of several additional broken, more separated perianth members below the intact parts (Fig. 1A-C), it is likely that the original number of tepals was greater, probably $30-40$. The androecium and gynoecium show both orthostichies and more or less clean parastichies with approximately the same inclination in both directions (Figs. 1G, H, 3D). Thus phyllotaxis is somewhat irregular but 
more or less whorled. The ca. 50 stamens are broad, scale-like, and spathulate (broadest distally and narrowest proximally) (Figs. 1E, H, J-L, 2A-D). Each stamen ends in a short sterile apical area (Fig. 1J-L). The attached stamens are $0.62-0.71 \mathrm{~mm}$ long and $0.36-0.44 \mathrm{~mm}$ in maximum width. The dispersed stamens that have been recovered are similar in shape to the in situ stamens, but they are larger (0.91-1.12 mm long, 0.59-0.79 mm maximum width; Fig. 2). The anther is ca. $2 / 3$ to $3 / 4$ the length of the stamen. The short sterile basal part of the stamen is not differentiated into a well-defined filament. The entire stamen tapers smoothly toward the base. The tip is bent toward the center of the flower, but no more than the rest of the anther, which is distinctly curved toward the center. The thecae, each with two pollen sacs (based on occasional remnants of a partition), are on the ventral (adaxial) surface (Figs. 1J-L, 3F-I). Thus the stamens are pronouncedly introrse. The pollen sacs appear to be embedded. The connective appears thicker than the thecae and the thecal flanks taper laterally into thin wings. The attachment point of each stamen is relatively narrow. Pollen cannot be seen in the anthers nor anywhere else on the flower, probably because the flower is at a preanthetic stage. The floral receptacle is hemispherical to almost 3/4 spherical in the gynoecial region (Fig. 3A-E). The flower contains ca. 100 carpels (Figs. 1D, E, G, H, 4A-H), which are ca. four times narrower than the stamens. The carpels are $0.27-0.43 \mathrm{~mm}$ long and 0.13-0.17 $\mathrm{mm}$ in maximum width. Seen in transverse section many of the carpels show a narrow gap in the ovary wall in the ventral median position (Fig. 4E-H). Thus the carpels are probably plicate at least at the level where the presumed margins are not connected. The carpels are short, somewhat cuneate, and the ovary locule takes up most of their length (Fig. 4A-H). Remains of ovules are not present, but from the small size and spheroidal shape of the locule it is likely that the carpels are uniovulate. A conspicuous style is not present. The distal part of the carpel is pointed and curved toward the center of the 
gynoecium (Fig. 4A-D). Seen in transverse section the carpels have a dorsal median rib and a short lateral wing on both sides, which may have been less prominent in live flowers. Mature fruit unknown.

\section{Phylogenetic Analyses.}

The results of the constrained analyses are shown in cladograms with Cecilanthus placed at one of its most parsimonious positions on each of the two backbone trees (Figs. 5-6). The thickest lines indicate branches to which the fossil attaches in the set of most parsimonious trees, while successively thinner lines indicate branches to which it attaches in trees that are one and two steps less parsimonious.

Analysis of the data set with anther dehiscence (76) and ovule number (112) scored as unknown and the D\&E backbone tree yielded six most parsimonious trees of 1020 steps (Fig. 5A). Analysis of the same data set with the $\mathrm{J} / \mathrm{M}$ backbone tree yielded two most parsimonious trees of 1030 steps (Fig. 6A). Analysis of the data set with anther dehiscence scored as H-valvate and ovule number scored as one per carpel yielded one most parsimonious tree of 1020 steps with the D\&E backbone tree (Fig. 5B), and three most parsimonious trees of 1031 steps with the $\mathrm{J} / \mathrm{M}$ tree (Fig. 6B). Unconstrained analysis with anther dehiscence and ovule number scored as unknown yielded 333 most parsimonious trees of 959 steps; unconstrained analysis with anther dehiscence scored as H-valvate and ovule number as one per carpel yielded 375 trees of 960 steps (summarized in the Discussion). Details of the positions of Cecilanthus in these analyses and the characters supporting them are described in the Discussion. 


\section{Discussion}

\section{Structural Interpretation}

The arrangement of floral parts in Cecilanthus merits further discussion. We evaluated floral phyllotaxis through study of digital transverse sections as well as surface views, taking into account criteria for recognition of spiral vs. whorled phyllotaxis (Endress 2006; Endress and Doyle 2007). Spiral organs form parastichies inclined at different angles in opposite directions but no orthostichies, whereas whorled organs form both orthostichies and parastichies, the latter inclined at the same angle in opposite directions. Renderings of the flower with perianth removed were used for unobstructed views of the androecium.

In Cecilanthus stamens and carpels form more or less regular orthostichies (some of them indicated by radial lines in Fig. 3D). This implies that the parts are whorled but somewhat irregular, as is often the case in flowers with numerous stamens and carpels (Endress 2006; Endress and Doyle 2007). Transverse sections and surface views show orthostichies of two superposed stamens (none definitely of three) and parastichies of two or three stamens. Transverse sections including the perianth do not contain enough cycles to show orthostichies, but in surface view there are cases where a scar appears to be lined up precisely with a tepal (Fig. $1 \mathrm{C}$, asterisks). Also, there are cases where two or more stamens continue an orthostichy beginning with a tepal (Fig. 3D, radiating lines, especially toward top and left). These observations suggest that there were at least four whorls of tepals.

Because the number of tepals, stamens, and carpels per whorl is high (each organ is many times narrower than the cirumference of the floral base at the level of attachment of the organs), it is 
likely that the whorls are in fact part of a complex-whorled system, in which the number of parts per whorl increases in successive whorls by production of parts in double positions (Staedler and Endress 2009; Endress and Doyle 2015). However, because the basal part of the flower with the attachment zone of the outermost whorls is not preserved, the onset of such whorl complexity cannot be reconstructed. Because of the observed continuity of parastichies from the perianth to the androecium, we infer that stamens occur at single positions within the androecium. The number of stamens per whorl is at least 10, perhaps 12 as seen in surface view, 12 or 13 in transverse sections. Four stamen whorls are seen in transverse sections, probably five in surface view.

The stamens are preanthetic and do not show anther dehiscence. In addition pollen is not preserved in the pollen sacs, which is often the case in charcoalified flowers in which the anthers have not dehisced. The preanthetic stage of development can make it more difficult to judge whether the pollen sacs are embedded or superficial. However, there is no visible convexity of the adaxial surface overlying the pollen sacs in surface views and in transverse sections, indicating that the pollen sacs are embedded (Figs. 1J-L, 3F-I).

Because details of anther dehiscence and especially pollen structure could be very helpful in evaluating relationships of Cecilanthus, we made a search of sieved residue for dispersed stamens. This revealed 15 isolated mature stamens that appear to belong to Cecilanthus, based on their shape and embedded pollen sacs and the lack of any other floral remains, except for Mauldinia, in the residue. Several show open holes in place of the pollen sacs (Fig. 2D), which may suggest H-valvate dehiscence (i.e., by laterally hinged flaps) followed by loss of the valves, 
although it is possible that the holes are due to loss of the whole outer wall of a theca with a simple longitudinal slit. Two specimens (Fig. 2A, B) show remnants of the outer theca wall that are strongly delimited by a distinct groove around the presumes valves. At least the more visible bases of the valves appear to be detached from the anther wall, which is strongly suggestive of H-valvate dehiscence.

Many of the carpels show a narrow gap in the ovary wall in the adaxial median position, and their lateral walls become thinner and more pointed toward the floral center (Fig. 4E-H). This suggests that this zone of the carpel is plicate rather than ascidiate (where the wall thickness is typically uniform all around the carpel). Either the carpels are too young to be completely postgenitally closed or the postgenital connection opened artificially in the weakest position during the drying or charcoalification process. Sometimes the adaxial gap appears to run down to the base, which could mean that the whole carpel was plicate. However, because this is uncertain and it is not known where the ovule or ovules were attached, we scored carpel form (97) as either plicate or intermediate (i.e., with both plicate and ascidiate zones below the stigma, with ovule attachment on the ascidiate zone). The presence of an adaxial gap does not necessarily mean that the mature fruits are dehiscent. No convincing stigmatic surface is observed in the renderings of the carpels. It is possible that the whole exposed surface of the carpel is receptive, or just the ventral area. As the flower is preanthetic the stigmatic surface may not yet be differentiated.

\section{Comparison with Extant Angiosperms}

Individual features of Cecilanthus, such as numerous undifferentiated tepals, numerous stamens lacking a well-differentiated filament, and numerous free carpels, occur in various extant taxa in 
the clade Magnoliidae (Magnoliales, Laurales, Canellales, Piperales: Cantino et al. 2007) and in the basal ANITA grade (Amborella, Nymphaeales, Austrobaileyales). However, its combination of features is not exhibited in any extant lineage of flowering plants.

Magnoliidae. In having an androecium and a gynoecium consisting of very many parts, Cecilanthus is similar to many Magnoliales (other than Myristicaceae). Of these it is most reminiscent of Annonaceae, in which the stamens and carpels are whorled (Leins and Erbar 1996; Endress and Armstrong 2011), rather than spiral as in Magnoliaceae, Degeneria (Degeneriaceae), Galbulimima (Himantandraceae), and Eupomatia (Eupomatiaceae). Some derived members of Annonaceae have over 100 carpels. The shape of the stamens in the fossil is similar to that in some relatively plesiomorphic Annonaceae (e.g., Anaxagorea, the sister group of all other Annonaceae; Maas and Westra 1984; Doyle and Le Thomas 1996; Scharaschkin and Doyle 2005, 2006; Endress and Armstrong 2011; Chatrou et al. 2012) in being truncate (spathulate) with a rounded sterile apex and having elongate thecae and embedded pollen sacs. However, the anthers in Cecilanthus are introrse, whereas in extant Annonaceae the anthers are consistently extrorse. Anthers are also extrorse in Degeneria, Galbulimima, and Myristicaceae (genera with unfused anthers), although they are introrse in Eupomatia and most Magnoliaceae (except Liriodendron) (Endress and Hufford 1989; Endress 1994). If Cecilanthus has H-valvate anther dehiscence, as suggested by the associated isolated stamens, it resembles Galbulimima, Degeneria, Eupomatia, and Annonaceae (the GDEA clade) but differs from Myristicaceae and most Magnoliaceae (except some Magnolioideae). The carpels are either intermediate or plicate, as in Annonaceae and other Magnoliales (Igersheim and Endress 1997). They are probably uniovulate, as also in a number of Annonaceae, such as Annona, Duguetieae, and many 
Malmeoideae, as well as in Myristicaceae and Galbulimima. Degeneria differs in having only one carpel, as do Myristicaceae, but this is an autapomorphy that would not rule out a sistergroup relationship with the fossil.

Cecilanthus differs most conspicuously from most extant Magnoliales in its perianth. In the fossil there are several whorls each made up of numerous narrow, strap-shaped tepals, whereas in extant Annonaceae the tepals are almost always arranged in three whorls of three, as is also the case in most Magnoliaceae. Exceptions that vary in the direction of the fossil but are less extreme are Toussaintia, which in some cases has more numerous and narrow, strap-like tepals (Le Thomas 1969; van Heusden 1992), a derived condition within Annonaceae (Doyle and Le Thomas 1996), and derived groups of Magnolioideae (e.g., Magnolia stellata, where the inner perianth parts appear to be formed in the androecial zone: Wróblewska et al. 2015). Degeneria has more perianth parts but they are spiral, while Eupomatia has no perianth (an autapomorphy). Degeneria, Galbulimima, Eupomatia, and Anaxagorea (Annonaceae) also differ from Cecilanthus in having inner staminodes (Endress 1984; Maas and Westra 1984; Scharaschkin and Doyle 2006; Endress and Armstrong 2011). The closest approach to Cecilanthus is in Galbulimima, which has numerous narrow organs outside the stamens that superficially resemble the tepals of Cecilanthus. However, these organs are spiral rather than whorled; since they intergrade with the stamens, like the inner staminodes, they are presumed to be outer staminodes (Endress 1977, 1984).

Among other Magnoliidae, Laurales such as Calycanthaceae (which are sister to the remainder of the order) and Atherospermataceae approach Cecilanthus in having large numbers of tepals, 
stamens, and carpels. However, these taxa have spiral floral phyllotaxis; more derived members such as Lauraceae have whorled phyllotaxis, but the number of parts is generally smaller. Stamens are variously specialized with basal glands and/or apically hinged flap dehiscence in groups other than Calycanthaceae (Sinocalycanthus dehisces by valves, but they are laterally hinged, i.e., H-valvate; Staedler et al. 2007), and in Calycanthaceae they are extrorse rather than introrse. The whole order differs from Cecilanthus in having a more or less well-developed hypanthium.

ANITA grade. Many members of the ANITA grade resemble Cecilanthus in having flowers with numerous parts, including undifferentiated tepals and stamens without a distinct filament, and their anthers are most commonly introrse, as in the fossil, rather than extrorse as in most Magnoliidae. However, they differ strongly from the fossil in other characters, most notably in having pronouncedly ascidiate rather than plicate carpels (Endress and Igersheim 2000; Endress 2005). Partial exceptions are Barclaya (Nymphaeaceae) and Illicium (Austrobaileyales), which have a plicate zone in the upper part of the carpel (in Illicium extending down to the single nearbasal ovule).

Amborella and extant Austrobaileyales differ from Cecilanthus in various characters, such as functionally unisexual flowers and pointed stamens in Amborella, unusually broad stamens with protruding thecae and inner staminodes in Austrobaileya, stamens with a distinct filament and a single carpel in Trimenia, and unisexual flowers and connate stamens in Schisandra (Endress, 1980, 1984, 1994; Endress and Sampson 1983). However, these are autapomorphies that might exclude Cecilanthus from each of the extant groups, but not from a stem relationship to 
Amborella or from positions sister to or nested within Austrobaileyales as a whole. More significantly, these taxa differ from the fossil in having uniformly spiral floral phyllotaxis.

By contrast, Nymphaeales resemble Cecilanthus in having whorled floral phyllotaxis, with relatively small numbers of parts in Cabombaceae but large numbers in Nymphaeaceae, associated with an increase in number of parts per whorl within the flower due to production of tepals and stamens in double positions (Endress 2001; Endress and Doyle 2007, 2015). Stamens vary between introrse (Nymphaeaceae), latrorse (Trithuria, Brasenia), and extrorse (Cabomba); the stamens most similar to Cecilanthus may be the cuneate stamens of Nuphar (which are reported to have H-valvate dehiscence: Hufford 1996). No Nymphaeales are like the fossil in having so many free carpels in several whorls; Cabombaceae have 3-18 free carpels, while the carpels in Nymphaeaceae form one whorl and are syncarpous.

\section{Comparison with Other Fossils}

Several other mid-Cretaceous fossil flowers resemble Cecilanthus in having bisexual flowers with numerous parts, but all differ in major respects. Endressinia, from the Aptian of Brazil (Mohr and Bernardes-de-Oliveira 2004), which phylogenetic analyses have placed at different positions within Magnoliales (Doyle and Endress 2010; Mohr et al. 2013; Massoni et al. 2015), has numerous free plicate carpels but relatively few tepals, plus gland-bearing staminodes toward the inside of the probable androecial zone. Another plant from the Aptian of Brazil, Schenkeriphyllum (Mohr et al. 2013), is generally similar. Archaeanthus, from near the AlbianCenomanian boundary in Kansas (Dilcher and Crane 1984), which is more securely linked with Magnoliaceae (Doyle and Endress 2010; Massoni et al. 2015), differs in having a perianth of 
three trimerous whorls and spirally arranged stamens and carpels. Virginianthus, from the Albian of Virginia (Friis et al. 1994), which is probably sister to either Calycanthaceae or the remaining Laurales (Doyle et al. 2008), has numerous tepals, stamens, and carpels, but the phyllotaxis is spiral, the stamens are extrorse, and there is a deep hypanthium, with inner staminodes on its rim. Araripia, from the Aptian of Brazil (Mohr and Eklund 2003), also has numerous parts and a deep hypanthium, but its floral architecture is poorly understood. Carpestella and Monetianthus, from the Albian of Virginia and Portugal (Friis et al. 2009; von Balthazar et al. 2008), which are probably both nested within Nymphaeaceae (Doyle and Endress 2014), have numerous tepals and stamens, possibly whorled, but they differ from Cecilanthus in having a single whorl of fused carpels and an inferior ovary.

\section{Phylogenetic Analyses}

Given the conflicting pattern of similarities and differences between Cecilanthus and extant lineages of angiosperms, we hoped that a phylogenetic analysis would help to clarify its most likely relationships. The results reflect the conflicting signals revealed by our comparative survey, but they bring the problems and possible solutions into clearer focus, and experiments assuming the most likely states of the anther dehiscence and ovule number characters suggest which solutions are most likely.

In the constrained analyses with the D\&E backbone tree and anther dehiscence (96) and ovule number (112) scored as unknown, Cecilanthus has six most parsimonious positions (1020 steps), in three disjunct areas of the tree (Fig. 5A). Two are nested within Nymphaeales, three are nested within Magnoliales, and one is sister to Laurales. Eleven positions are one step less 
parsimonious, including sister to Nuphar or Barclaya, sister to Magnoliales or to both Magnoliales and Laurales, nested in Laurales, and linked with the eudicot Nelumbo.

The two positions in Nymphaeales are (1) sister to Nymphaeaceae and (2) nested within Nymphaeaceae as the sister group of Barclaya and Nymphaeoideae (Nymphaea, Euryale, Victoria). Unequivocal (i.e., unambiguously placed) synapomorphies that support the first position of Cecilanthus are truncate anther connective (72), shared with Nymphaeales as a whole; and polymerous androecium (64, i.e., more than three stamens per whorl), short stamen base (70), and embedded pollen sacs (73), shared with Nymphaeaceae. Other characters that are not definitely synapomorphies (because of ambiguous polarity) but support this position over one in Magnoliales, by undergoing fewer steps across the tree, are whorled androecium (63) and introrse anthers (75). This tree implies that Cecilanthus diverged from an ancestor of Nymphaeaceae in which the carpels had increased in number but were still free. The plicate or intermediate carpel (97) of Cecilanthus is a convergence with Magnoliidae and therefore represents evidence against this position. In the second position, Cecilanthus is linked with Barclaya and Nymphaeoideae by a shift from the trimerous perianth seen in Cabombaceae and Nuphar to a polymerous perianth (55); however, this position requires an extra step in the carpel fusion character (106), since syncarpy must either evolve twice (in Nuphar and in other Nymphaeaceae) or be reversed in the fossil. Both positions predict that Cecilanthus had more than two ovules per carpel (112), a synapomorphy of Cabombaceae and Nymphaeaceae when only living groups are considered. 
The three positions of Cecilanthus in Magnoliales are sister to (1) all members of the order other than Myristicaceae, (2) Magnoliaceae, and (3) the clade consisting of Galbulimima, Degeneria, Eupomatia, and Annonaceae (GDEA). Synapomorphies supporting all three positions are plicate carpel (97), shared with Magnoliidae, monocots and eudicots; more than two whorls of stamens (65), short stamen base (70), and more than one whorl of carpels (96), which are synapomorphies of Magnoliales and Laurales; and embedded pollen sacs (73), shared with all Magnoliales except Myristicaceae. In these three positions, various combinations of polymerous perianth (55), whorled androecium (63), polymerous androecium (64), and introrse anthers (75) are convergences with Nymphaeales, confirming the intuition that these characters pose problems for assignment to Magnoliales. Cecilanthus is excluded from the GDEA clade by lack of inner staminodes (68), food bodies on stamens or staminodes (69), and extended connective apex (72), which are synapomorphies of this clade.

Since relationships within Magnoliales are uncertain (Massoni et al. 2014), we also assessed the position of Cecilanthus on a tree in which Magnoliaceae are sister to Galbulimima and Degeneria, the main alternative found by Massoni et al. (2014). On this tree, its single most parsimonious position in Magnoliales is sister to Magnoliaceae.

The position of Cecilanthus as the sister group of Laurales is supported by plicate carpels (97), more than two stamen whorls (65), short stamen base (70), and more than one whorl of carpels (96), as in trees with the fossil in Magnoliales, plus polymerous perianth (55) and androecium (64), shared with Laurales. Its position outside crown Laurales is supported by lack of a hypanthium (48) and inner staminodes (68) and the whorled perianth (54), which becomes spiral 
at the base of Laurales. However, the two synapomorphies shared with Laurales may be artifacts of character definition. The members of Laurales that have a polymerous perianth are some Hernandiaceae (Gyrocarpoideae, some Hernandioideae), and some Mollinedioideae (Monimiaceae), all deeply nested within Laurales, and a polymerous androecium is found in Hernandiaceae and some Mollinedioideae. The algorithm treats these cases as homologous with the conditions in Cecilanthus because the intervening taxa (except Lauraceae) have spiral or polymorphic phyllotaxis and were therefore scored as unknown (inapplicable) for merism; as a result, the algorithm implicitly treats the spiral taxa as having the polymerous condition (an example of a general effect noted by Maddison, 1993).

The one step less parsimonious position of Cecilanthus with Nelumbo, which would imply that the fossil had tricolpate pollen, is sufficiently surprising to merit some attention. Derived features shared by the two taxa are more than two androecial whorls (or series), more than one whorl (or series) of carpels, and sessile stigma. However, the androecium of Nelumbo is very different in developing from a secondary ring primordium (Hayes et al. 2000), on which the numerous stamens have no regular phyllotaxis (neither spiral nor whorled), a developmental pattern not known in any Magnoliidae nor ANITA lines (Endress 2011). Although strictly speaking it has neither whorls nor series, we assigned it to the same state as more than two whorls because it shows more than two stamens in longitudinal section (or radial direction).

This situation becomes markedly less ambiguous when anther dehiscence (96) is scored as Hvalvate, based on the probably related isolated stamens, and ovule number (112) as one per carpel, based on the small size and spheroidal shape of the carpel locule. In this case, 
Cecilanthus has only one most parsimonious position on the D\&E backbone tree (Fig. 5B), namely nested in Magnoliales as the sister group of the GDEA clade. This is supported by the Hvalvate anthers of the two groups. Of the other most parsimonious positions found when the anther and ovule characters are scored as unknown, the two in Magnoliales and the one sister to Laurales are one step less parsimonious, but positions in Nymphaeales are two steps worse, since the ovule number character undergoes one extra step when Cecilanthus is nested in Nymphaeaceae.

With the $\mathrm{J} / \mathrm{M}$ backbone constraint tree and anther dehiscence and ovule number scored as unknown (Fig. 6A), Cecilanthus has two most parsimonious positions (1030 steps): sister to Laurales, and sister to Chloranthaceae (which are the sister group of Magnoliidae in the J/M tree). The five most parsimonious positions in Nymphaeales and Magnoliales found with the D\&E backbone are one step less parsimonious, along with seven other positions.

Unequivocal synapomorphies that support a sister-group relationship of Cecilanthus and Laurales are more than one whorl of carpels (96), shared with both Magnoliales and Laurales, and polymerous perianth (55) and androecium (64), as with the D\&E backbone; the last two characters are problematical for the reasons discussed above. Again, Cecilanthus is excluded from crown Laurales by its whorled stamens and lack of hypanthium and inner staminodes.

The only unequivocal synapomorphy uniting Cecilanthus with Chloranthaceae is embedded pollen sacs (73), since the polarity of many other characters of the fossil is ambiguous on this tree. Its polymerous perianth (55) is an autapomorphy. This result would imply that Cecilanthus 
diverged from Chloranthaceae before the extreme floral reduction characteristic of the living clade.

With the $\mathrm{J} / \mathrm{M}$ backbone tree, establishing that Cecilanthus had H-valvate anthers and uniovulate carpels would increase the relative parsimony of a position in Magnoliales. With these characters scored, Cecilanthus has three most parsimonious positions (Fig. 6B). These are sister to Laurales and to Chloranthaceae, as with the two characters scored as unknown, plus the position found with the D\&E backbone: nested within Magnoliales as the sister group of the GDEA clade, supported by H-valvate anthers. Two other positions in Magnoliales are one step less parsimonious, while the three best positions in Nymphaeales are two steps less parsimonious, as found with the D\&E backbone. Given the uncertainty on mesangiosperm relationships, as expressed by the D\&E and $\mathrm{J} / \mathrm{M}$ trees, this analysis suggests that it would be premature to assume that the position of Cecilanthus in Magnoliales is correct, but it confirms that this is among the best alternatives.

Except for the positions sister to Laurales and Chloranthaceae, the most parsimonious positions found for Cecilanthus conform to a tendency of previous phylogenetic analyses to place Early and mid-Cretaceous taxa within living major clades, usually orders in the APG (2009) system, where they are often sister to one or a few families (Doyle and Endress 2010, 2014), rather than on internal branches linking these clades. In Cecilanthus, the numerous parts and introrse anthers might suggest a sister-group relationship to Austrobaileyales, assuming that the spiral phyllotaxis of this order is derived (in terms of parsimony it may be either ancestral or derived; Endress and Doyle 2009). However, this is two or three steps less parsimonious than the best positions (Figs. 
$5,6)$, as a result of the embedded pollen sacs and the plicate or intermediate carpels of the fossil. These observations raise the question of whether the lack of recognition of extinct lines at this systematic level is due to some bias in phylogenetic methods. We see no reason to suspect that this is true; theoretically, phylogenetic methods should be perfectly capable of recognizing that fossils were attached to the stem lineages of higher-level clades. Results to date may therefore be evidence that by the mid-Cretaceous most of the angiosperm flora consisted of major clades that have survived until today, and that most other lines that may have existed earlier had become extinct or highly restricted.

In order to evaluate whether use of a molecular scaffold approach may have given positions of Cecilanthus that would be unparsimonious in terms of morphology alone, we also conducted unconstrained morphological analyses of the data set. As in the similar analysis of Doyle and Endress (2000), these analyses recovered many of the same major clades found with molecular data, such as Nymphaeales, Magnoliales, Laurales, Canellales, Piperales, and monocots, but some relationships among these clades are very different. Most notably eudicots arise once but are paraphyletic, with Piperales, monocots, and (in some trees) Nymphaeales nested within them. Such relationships were overruled by molecular data in the combined molecular-morphological analysis of Doyle and Endress (2000).

With anther dehiscence and ovule number of Cecilanthus treated as unknown, the analysis yielded 333 most parsimonious trees of 959 steps (not shown). This large number of trees is due mostly to multiple arrangements among living taxa, not to increased uncertainty on the position of Cecilanthus. Positions of the fossil overlap with those found in the constrained analyses: it is 
either sister to Laurales or nested within Nymphaeales, sister to Nymphaeaceae. However, positions nested in Magnoliales are only one step less parsimonious. With anther dehiscence scored as H-valvate and ovule number scored as one, we obtained 375 trees of 960 steps. In all trees, Cecilanthus is either sister to Laurales or nested within Magnoliales, sister to the GDEA clade. This again illustrates how the anther and ovule number characters, if confirmed, would weaken a position nested in Nymphaeales and strengthen one nested in Magnoliales.

\section{Conclusions}

Given the preponderance of available character information, we suspect that Cecilanthus belongs in Magnoliales rather than in Nymphaeales, and those of its features that are anomalous in Magnoliales, like the introrse anthers and polymerous whorls of parts, are convergences with the ANITA grade. However, more isolated positions on the stem lineages of major groups, such as Laurales, are also possible.

Both broad comparative and explicitly phylogenetic approaches indicate that many described Early and mid-Cretaceous angiosperms can be assigned to major living clades (often orders) and often placed on stem lineages of particular families of Magnoliidae, the ANITA groups, Chloranthaceae, and basal eudicots (Friis et al. 2006, 2011; Doyle and Endress 2010, 2014; Doyle 2015). However, whether Cecilanthus is magnolialean or nymphaealean or represents a more isolated line in mesangiosperms, it demonstrates that the Early Cretaceous radiation of angiosperms produced floral morphotypes that were markedly different from those of any surviving groups. 
Although Cecilanthus is well preserved and most floral architecture characters are available, our results illustrate the fact that additional characters are sometimes needed to reach an unequivocal phylogenetic placement of fossil flowers. For example, seeds with palisade exotesta and an operculum would favor a position in Nymphaeales, whereas alternative features of seed anatomy would favor a position in Magnoliales or elsewhere in Magnoliidae. In most positions found, pollen would most likely be monosulcate with columellar infratectal structure; however, this might be associated with a continuous tectum in Nymphaeales but a reticulate tectum among near-basal Magnoliales or on the lines leading to Laurales or to Chloranthaceae (cf. Doyle 2005). However, if Cecilanthus is sister to the GDEA clade in Magnoliales, its exine might be either columellar or granular, with a continuous tectum, as in Galbulimima, Degeneria, Eupomatia, and Annonaceae such as the basal genus Anaxagorea. This underlines how valuable pollen and seed characters have been in placing many previously described Cretaceous floral mesofossils and how their discovery is a priority for future studies. Association of this and other flowers with vegetative remains, a more difficult goal, could be equally informative, as could exploration of the data with new methods.

\section{Acknowledgements}

PSH thanks Sara Johansen Lowe for assistance in the lab and field. We thank Ashley Klymiuk, Stefan Little, and Selena Smith for inviting us to the symposium in honor of Ruth Stockey at which this work was presented. We thank Hervé Sauquet and an anonymous reviewer for suggesting improvements on the manuscript. Use of the Advanced Photon Source, an Office of

Science User Facility, operated for the U. S. Department of Energy (DOE) Office of Science by 
Argonne National Laboratory, was supported by the U. S. DOE under Contract no. DE-AC02$06 \mathrm{CH} 11357$. 


\section{Literature Cited}

APG (Angiosperm Phylogeny Group) III. 2009. An update of the Angiosperm Phylogeny Group classification for the orders and families of flowering plants: APG III. Bot. J. Linn. Soc. 161: 105-121.

Brenner, G.J. 1963. The spores and pollen of the Potomac Group of Maryland. Md. Dep. Geol. Mines Water Resour. Bull. 27: 1-215.

Cantino, P.D., Doyle, J.A., Graham, S.W., Judd, W.S., Olmstead, R.G., Soltis, D.E., Soltis, P.S., and Donoghue, M.J. 2007. Towards a phylogenetic nomenclature of Tracheophyta. Taxon 56: 822-846.

Chatrou, L.W., Pirie, M.D., Erkens, R.H.J., Couvreur, T.L.P., Neubig, K.M., Abbott, J.R., Mols, J.B., Maas, J.W., Saunders, R.M.K., and Chase, M.W. 2012. A new subfamilial and tribal classification of the pantropical flowering plant family Annonaceae informed by molecular phylogenetics. Bot. J. Linn. Soc. 169: 5-40.

Dilcher, D.L., and Crane, P.R. 1984. Archaeanthus: an early angiosperm from the Cenomanian of the Western Interior of North America. Ann. Mo. Bot. Gard. 71: 351-383.

Doyle, J.A. 2005. Early evolution of angiosperm pollen as inferred from molecular and morphological phylogenetic analyses. Grana 44: 227-251.

Doyle, J.A. 2015. Recognising angiosperm clades in the Early Cretaceous fossil record. Hist. Biol. 27: 414-429.

Doyle, J.A., and Endress, P.K. 2000. Morphological phylogenetic analysis of basal angiosperms: comparison and combination with molecular data. Int. J. Plant Sci. 161(Suppl.): S121S153. 
Doyle, J.A., and Endress, P.K. 2010. Integrating Early Cretaceous fossils into the phylogeny of living angiosperms: Magnoliidae and eudicots. J. Syst. Evol. 48: 1-35.

Doyle, J.A., and Endress, P.K. 2014. Integrating Early Cretaceous fossils into the phylogeny of living angiosperms: ANITA lines and relatives of Chloranthaceae. Int. J. Plant Sci. 175: $555-600$.

Doyle, J.A., and Le Thomas, A. 1996. Phylogenetic analysis and character evolution in Annonaceae. Bull. Mus. Natl. Hist. Nat., Sect. B: Adansonia 18: 279-334.

Doyle, J.A., and Robbins, E.I. 1977. Angiosperm pollen zonation of the continental Cretaceous of the Atlantic Coastal Plain and its application to deep wells in the Salisbury Embayment. Palynology 1: 43-78.

Doyle, J.A., Endress, P.K., and Upchurch, G.R. Jr. 2008. Early Cretaceous monocots: a phylogenetic evaluation. Acta Mus. Natl. Pragae, Ser. B 64(2-4): 59-87.

Drinnan, A.N., Crane, P.R., Friis, E.M., and Pedersen, K.R. 1990. Lauraceous flowers from the Potomac Group (mid-Cretaceous) of eastern North America. Bot. Gaz. 151: 370-384.

Drinnan, A.N., Crane, P.R., Friis, E.M., and Pedersen, K.R. 1991. Angiosperm flowers and tricolpate pollen of buxaceous affinity from the Potomac Group (mid-Cretaceous) of eastern North America. Am. J. Bot. 78: 153-176.

Endress, P.K. 1977. Über Blütenbau und Verwandtschaft der Eupomatiaceae und Himantandraceae (Magnoliales). Ber. Dtsch. Bot. Ges. 90: 83-103.

Endress, P.K. 1980. The reproductive structures and systematic position of the Austrobaileyaceae. Bot. Jahrb. Syst. 101: 393-433.

Endress, P.K. 1984. The role of inner staminodes in the floral display of some relic Magnoliales. Plant Syst. Evol. 146: 269-282. 
Endress, P.K. 1994. Shapes, sizes and evolutionary trends in stamens of Magnoliidae. Bot. Jahrb. Syst. 115: 429-460.

Endress, P.K. 2001. The flowers in extant basal angiosperms and inferences on ancestral flowers. Int. J. Plant Sci. 162: 1111-1140.

Endress, P.K. 2005. Carpels in Brasenia (Cabombaceae) are completely ascidiate despite a long stigmatic crest. Ann. Bot. 96: 209-215.

Endress, P.K. 2006. Angiosperm floral evolution: morphological developmental framework. Adv. Bot. Res. 44: 1-61.

Endress, P.K. 2011. Evolutionary diversification of the flowers in angiosperms. Am. J. Bot. 98 : $370-396$.

Endress, P.K., and Armstrong, J.E. 2011. Floral development and floral phyllotaxis in Anaxagorea (Annonaceae). Ann. Bot. 108: 835-845.

Endress, P.K., and Doyle, J.A. 2007. Floral phyllotaxis in basal angiosperms - development and evolution. Curr. Opin. Plant Biol. 10: 52-57.

Endress, P.K., and Doyle, J.A. 2009. Reconstructing the ancestral flower and its initial specializations. Am. J. Bot. 96: 22-66.

Endress, P.K., and Doyle, J.A. 2015. Ancestral traits and specializations in the flowers of the basal grade of living angiosperms. Taxon 64: 1093-1116.

Endress, P.K., and Hufford, L.D. 1989. The diversity of stamen structures and dehiscence patterns among Magnoliidae. Bot. J. Linn. Soc. 100: 45-85.

Endress, P.K., and Igersheim, A. 2000. Gynoecium structure and evolution in basal angiosperms. Int. J. Plant Sci. 161: S211-S223. 
Endress, P.K., and Sampson, F.B. 1983. Floral structure and relationships of the Trimeniaceae (Laurales). J. Arnold Arbor. 64: 447-473.

Friis, E.M., Eklund, H., Pedersen, K.R., and Crane, P.R. 1994. Virginianthus calycanthoides gen. et sp. nov. - a calycanthaceous flower from the Potomac Group (Early Cretaceous) of eastern North America. Int. J. Plant Sci. 155: 772-785.

Friis, E.M., Pedersen, K.R., and Crane, P.R. 2006. Cretaceous angiosperm flowers: innovation and evolution in plant reproduction. Palaeogeogr. Palaeoclimatol. Palaeoecol. 232: 251293.

Friis, E.M., Crane, P.R., Pedersen, K.R., Bengtson, S., Donoghue, P.C.J., Grimm, G.W., and Stampanoni, M. 2007. Phase-contrast X-ray microtomography links Cretaceous seeds with Gnetales and Bennettitales. Nature 450: 549-552.

Friis, E.M., Pedersen, K.R., von Balthazar, M., Grimm, G.W., and Crane, P.R. 2009. Monetianthus mirus gen. et sp. nov., a nymphaealean flower from the Early Cretaceous of Portugal. Int. J. Plant Sci. 170: 1086-1101.

Friis, E.M., Crane, P.R, and Pedersen, K.R. 2011. Early flowers and angiosperm evolution. Cambridge University Press, Cambridge, UK.

Hayes, V., Schneider, E.L., and Carlquist, S. 2000. Floral development of Nelumbo nucifera (Nelumbonaceae). Int. J. Plant Sci. 161: S183-S191.

Hufford, L.D. 1996. The origin and early evolution of angiosperm stamens. In The anther. Form, function and phylogeny. Edited by W.G. D'Arcy and R.C. Keating. Cambridge University Press, Cambridge, UK. pp. 58-91.

Igersheim, A., and Endress, P.K. 1997. Gynoecium diversity and systematics of the Magnoliales and winteroids. Bot. J. Linn. Soc. 124: 213-271. 
Jansen, R.K., Cai, Z., Raubeson, L.A., Daniell, H., dePamphilis, C.W., Leebens-Mack, J., Müller, K.F., Guisinger-Bellian, M., Haberle, R.C., Hansen, A.K., Chumley, T.W., Lee, S.B., Peery, R., McNeal, J.R., Kuehl, J.V., and Boore, J.L. 2007. Analysis of 81 genes from 64 plastid genomes resolves relationships in angiosperms and identifies genome-scale evolutionary patterns. Proc. Natl. Acad. Sci. U. S. A. 104: 19369-19374.

Le Thomas, A. 1969. Annonaceae. Flore du Gabon No. 16. Edited by A. Aubréville. Muséum National d'Histoire Naturelle, Paris.

Leins, P., and Erbar, C. 1996. Early floral developmental studies in Annonaceae. In Reproductive morphology in Annonaceae. Edited by W. Morawetz and H. Winkler. Biosyst. Ecol. Ser. 10. Austrian Academy of Sciences Press, Vienna. pp. 1-27.

Maas, P.J.M., and Westra, L.Y.T. 1984. Studies in Annonaceae. II. A monograph of the genus Anaxagorea A. St. Hil., Part 1. Bot. Jahrb. Syst. 105: 73-134.

Maddison, D.R., and Maddison, W.P. 2003. MacClade 4: analysis of phylogeny and character evolution, version 4.06. Sinauer Associates, Sunderland, Mass.

Maddison, W.P. 1993. Missing data versus missing characters in phylogenetic analysis. Syst. Biol. 42: 576-581.

Massoni, J., Forest, F., Sauquet, H., 2014. Increased sampling of both genes and taxa improves resolution of phylogenetic relationships within Magnoliidae, a large and early-diverging clade of angiosperms. Mol. Phylogenet. Evol. 70: 84-93.

Massoni, J., Doyle, J., and Sauquet, H. 2015. Fossil calibration of Magnoliidae, an ancient lineage of angiosperms. Palaeontol. Electron. 17(3), 2FC, 25 pp. 
Mohr, B.A.R., and Bernardes-de-Oliveira, M.E.C. 2004. Endressinia brasiliana, a magnolialean angiosperm from the Lower Cretaceous Crato Formation (Brazil). Int. J. Plant Sci. 165: 1121-1133.

Moore, M.J., Bell, C.D., Soltis, P.S., and Soltis, D.E. 2007. Using plastid genome-scale data to resolve enigmatic relationships among basal angiosperms. Proc. Natl. Acad. Sci. U. S. A. 104: 19363-19368.

Mohr, B.A.R., Coiffard, C., and Bernardes-de-Oliveira, M.E.C. 2013. Schenkeriphyllum glanduliferum, a new magnolialean angiosperm from the Early Cretaceous of Northern Gondwana and its relationships to fossil and modern Magnoliales. Rev. Palaeobot. Palynol. 189: 57-72.

Mohr, B.A.R., and Eklund, H. 2003. Araripia florifera, a magnoliid angiosperm from the Lower Cretaceous Crato Formation (Brazil). Rev. Palaeobot. Palynol. 126: 279-292.

Ogg, J. G., and Hinnov, L.A. 2012. Cretaceous. In The geologic time scale 2012. Edited by F.M. Gradstein, J.G. Ogg, M.D. Schmitz, and G.M. Ogg. Elsevier, Amsterdam. pp. 793-853.

Pedersen, K.R., Crane, P.R., Drinnan, A.N., and Friis, E.M. 1991. Fruits from the midCretaceous of North America with pollen grains of the Clavatipollenites type. Grana 30: 577-590.

Ruhfel, B.R., Gitzendanner, M.A., Soltis, P.S., Soltis, D.E., and Burleigh, J.G. 2014. From algae to angiosperms - inferring the phylogeny of green plants (Viridiplantae) from 360 plastid genomes. BMC Evol. Biol. 14:23.

Scharaschkin, T., and Doyle, J.A. 2005. Phylogeny and historical biogeography of Anaxagorea (Annonaceae) using morphology and non-coding chloroplast sequence data. Syst. Bot. 30: 712-735. 
Scharaschkin, T., and Doyle, J.A. 2006. Character evolution in Anaxagorea (Annonaceae). Am. J. Bot. 93: 36-54.

Schönenberger, J., von Balthazar, M., Takahashi, M., Xiao, X., Crane, P.R., and Herendeen, P.S. 2012. Glandulocalyx upatoiensis, a fossil flower of Ericales (Actinidiaceae/Clethraceae) from the Late Cretaceous (Santonian) of Georgia, USA. Ann. Bot. 109: 921-936.

Springer, M.S., Teeling, E.C., Madsen, O., Stanhope, M.J., and de Jong, W.W. 2001. Integrated fossil and molecular data reconstruct bat echolocation. Proc. Natl. Acad. Sci. U. S. A. 98 : $6241-6246$.

Staedler, Y.M., and Endress, P.K. 2009. Diversity and lability of floral phyllotaxis in the pluricarpellate families of core Laurales (Gomortegaceae, Atherospermataceae, Siparunaceae, Monimiaceae). Int. J. Plant Sci. 170: 522-550.

Staedler, Y.M., Weston, P.H., and Endress, P.K. 2007. Floral phyllotaxis and floral architecture in Calycanthaceae (Laurales). Int. J. Plant Sci. 168: 285-306.

Swofford, D.L. 1990. PAUP: phylogenetic analysis using parsimony, version 3.0. Illinois Natural History Survey, Champaign.

Takahashi, M., Friis, E.M., Uesugi, K., Suzuki, Y., and Crane, P.R. 2008a. Floral evidence of Annonaceae from the Late Cretaceous of Japan. Int. J. Plant Sci. 169: 908-917.

Takahashi, M., Friis, E.M., Herendeen, P.S., and Crane, P.R. 2008b. Fossil flowers of Fagales from the Kamikitaba locality (Early Coniacian); Late Cretaceous) of northwestern Japan. Int. J. Plant Sci. 169: 899-907.

Takahashi, M., Herendeen, P.S., Xiao, X., and Crane, P.R. 2014. Lauraceous fossil flowers from the Kamikitaba assemblage (Coniacian, Late Cretaceous) of northeastern Japan. Syst. Bot. 39: $715-724$. 
van Heusden, E.C.H. 1992. Flowers of Annonaceae: Morphology, classification, and evolution. Blumea, Suppl. 7: 1-218.

von Balthazar, M., Pedersen, K.R., Crane, P.R., Stampanoni, M., and Friis, E.M. 2007.

Potomacanthus lobatus gen. et sp. nov., a new flower of probable Lauraceae from the Early Cretaceous (Early to Middle Albian) of eastern North America. Am. J. Bot. 94: 2041-2053. von Balthazar, M., Pedersen, K.R., Crane, P.R., and Friis, E.M. 2008. Carpestella lacunata gen. et sp. nov., a new basal angiosperm flower from the Early Cretaceous (Early to Middle Albian) of eastern North America. Int. J. Plant Sci. 169: 890-898.

Wróblewska, M., Dołzbłasz, A., and Zagórska-Marek, B. 2015. The role of ABC genes in shaping perianth phenotype in the basal angiosperm Magnolia. Plant Biol. doi:10.1111/plb.12392, 9 pp. 
Figure Captions

Figure 1. Synchrotron X-ray tomography renderings of fossil flower: external morphology. Specimen PP55896. A. Lateral view of flower showing pedicel with scars of floral parts that have been lost, as well as tepals, stamens, and apex of gynoecium in center. B. Lateral view of flower rotated $90^{\circ}$. C. Reverse side of flower from Fig. 1A. Asterisks indicate orthostichies where a tepal scar appears to be lined up precisely with a tepal. D. Oblique view of flower showing tepals and numerous free carpels in the center. E. Same view of flower as Fig. 1D with perianth digitally removed showing spathulate stamens and numerous carpels. F. Same view as in Fig. 1D, E with androecium and gynoecium digitally removed showing incomplete perianth. G. Apical view of flower showing tepals, spathulate stamens, and numerous free carpels in the center. H. Same view of flower as Fig. $1 \mathrm{G}$ with perianth digitally removed showing spathulate stamens and numerous carpels. I. Same view as in Fig. $1 \mathrm{G}, \mathrm{H}$ with androecium and gynoecium digitally removed showing incomplete perianth. J. Adaxial view of six stamens digitally removed from the flower showing poor differentiation between anther and filament and elongate thecae. K. Oblique view of stamens showing elongate adaxial thecae with likely embedded pollen sacs. Outer wall of thecae is incompletely preserved. L. Frontal and oblique views of stamens to show position and form of thecae.

Figure 2. A-D. Dispersed stamens recovered from the same sample as the fossil flower specimen. A. Broken stamen with remnants of the outer theca wall suggestive of $\mathrm{H}$-valve dehiscence. Specimen PP55897. B. Stamen showing likely embedded pollen sacs. Tapering base is incomplete. Specimen PP55898. C. Stamen showing likely embedded pollen sacs. Base of 
specimen is incomplete. Specimen PP558999. D. Lateral view of stamen showing theca with outer wall missing. Specimen PP559000.

Figure 3. Synchrotron X-ray tomography renderings of fossil flower: longitudinal and transverse sections. Specimen PP55896. A. Three dimensional rendering, median longitudinal section of flower. B. Two dimensional rendering, medial longitudinal section of flower. C-E. Transverse sections from near apex (C), center (D), and base (E). C. Transverse sections of several tepals are present. The spongy central receptacle is evident with attached carpels. Arrows indicate carpels showing a narrow gap in the ovary wall in the ventral median position. D. Section shows carpels attached to receptacle and transverse sections of spathulate stamens and tepals. Arrow indicates a stamen with embedded pollen sacs. Radiating lines indicate orthostichies in stamens and tepals. E. Section shows transverse views of spathulate stamens and tepals. F, G. Longitudinal sections of stamens showing pollen sacs. Incomplete wall between adjacent pollen sacs seen in G. H, I. Lateral longitudinal section of stamens showing embedded pollen sacs.

Figure 4. Synchrotron X-ray tomography renderings of fossil flower: longitudinal and transverse sections of carpels. Specimen PP55896. A-D. Longitudinal sections of carpels to show locule size and shape and apical projection of carpel beyond ovary. E-H. Transverse sections of carpels to show locule size and shape and narrow gap in the ovary wall in ventral median position.

Figure 5. Phylogenetic analyses of the position of Cecilanthus with the D\&E backbone constraint tree, with the fossil placed at one of its most parsimonious positions. Other most parsimonious, one step less parsimonious, and two steps less parsimonious positions indicated by successively 
thinner lines. A, results with anther dehiscence and ovule number scored as unknown. B, results with anther dehiscence (76) scored as H-valvate and ovule number (112) as one per carpel. Abbreviations: Nymph $=$ Nymphaeales, Aust $=$ Austrobaileyales, Chlor $=$ Chloranthaceae, Piper $=$ Piperales, $\mathrm{Ca}=$ Canellales, Magnol $=$ Magnoliales .

Figure 6. Phylogenetic analyses of the position of Cecilanthus with the J/M backbone constraint tree. See Fig. 5 for conventions. A, results with anther dehiscence and ovule number scored as unknown. B, results with anther dehiscence (76) scored as H-valvate and ovule number (112) as one per carpel. 


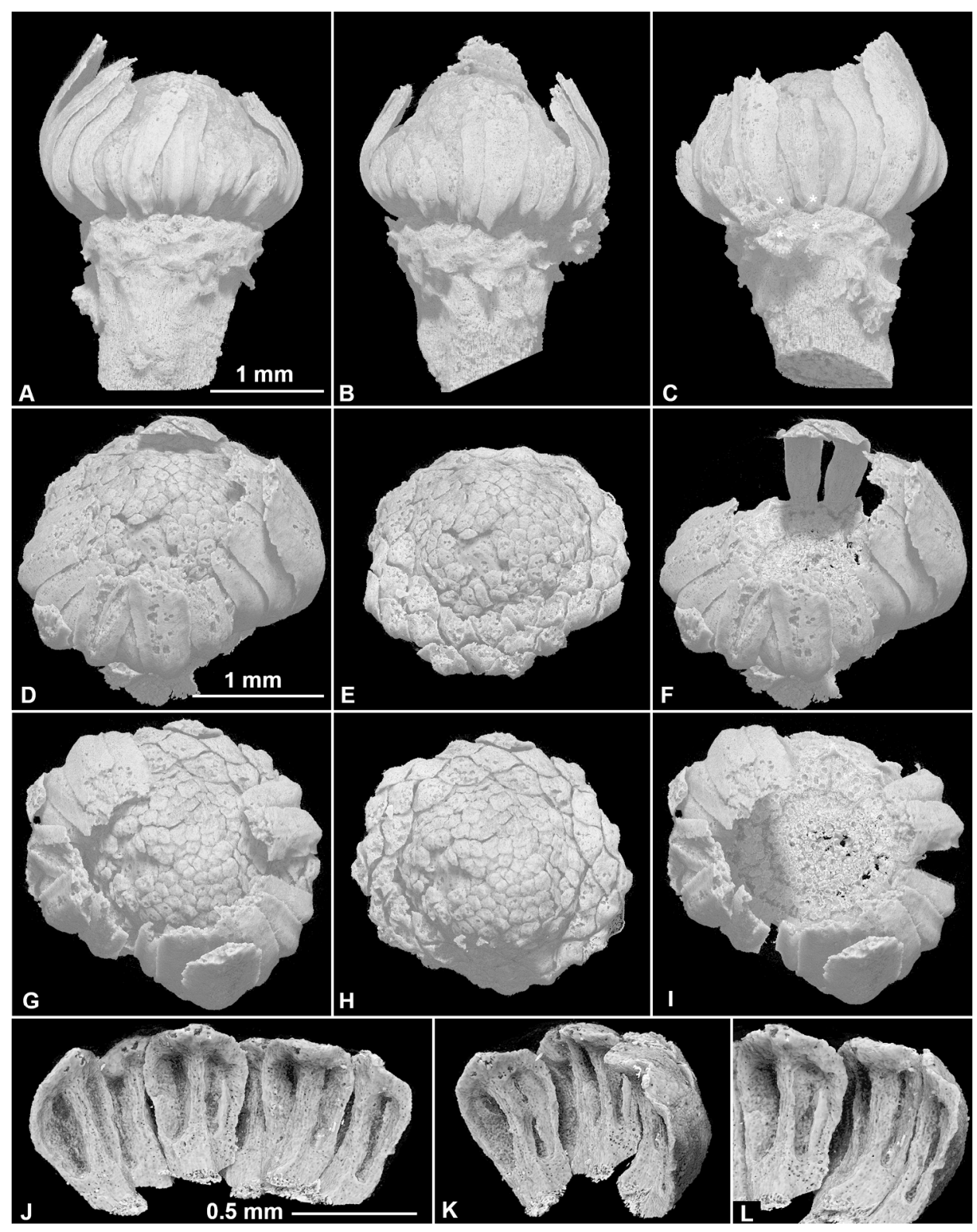

Figure 1. Synchrotron X-ray tomography renderings of fossil flower: external morphology. Specimen PP55896. A. Lateral view of flower showing pedicel with scars of floral parts that have been lost, as well as tepals, stamens, and apex of gynoecium in center. B. Lateral view of flower rotated $90^{\circ}$. C. Reverse side of flower from Fig. 1A. Asterisks indicate orthostichies where a tepal scar appears to be lined up precisely with a tepal. D. Oblique view of flower showing tepals and numerous free carpels in the center. E. Same view of flower as Fig. 1D with perianth digitally removed showing spathulate stamens and numerous carpels. F. Same view as in Fig. 1D, E with androecium and gynoecium digitally removed showing incomplete perianth. G. Apical view of flower showing tepals, spathulate stamens, and numerous free carpels in the center. $H$. Same view of flower as Fig. $1 \mathrm{G}$ with perianth digitally removed showing spathulate stamens and numerous carpels. I. Same view as in Fig. 1G, H with androecium and gynoecium digitally removed showing

incomplete perianth. J. Adaxial view of six stamens digitally removed from the flower showing poor differentiation between anther and filament and elongate thecae. K. Oblique view of stamens showing elongate adaxial thecae with likely embedded pollen sacs. Outer wall of thecae is incompletely preserved. $\mathrm{L}$. 
Frontal and oblique views of stamens to show position and form of thecae. $181 \times 229 \mathrm{~mm}(300 \times 300 \mathrm{DPI})$ 

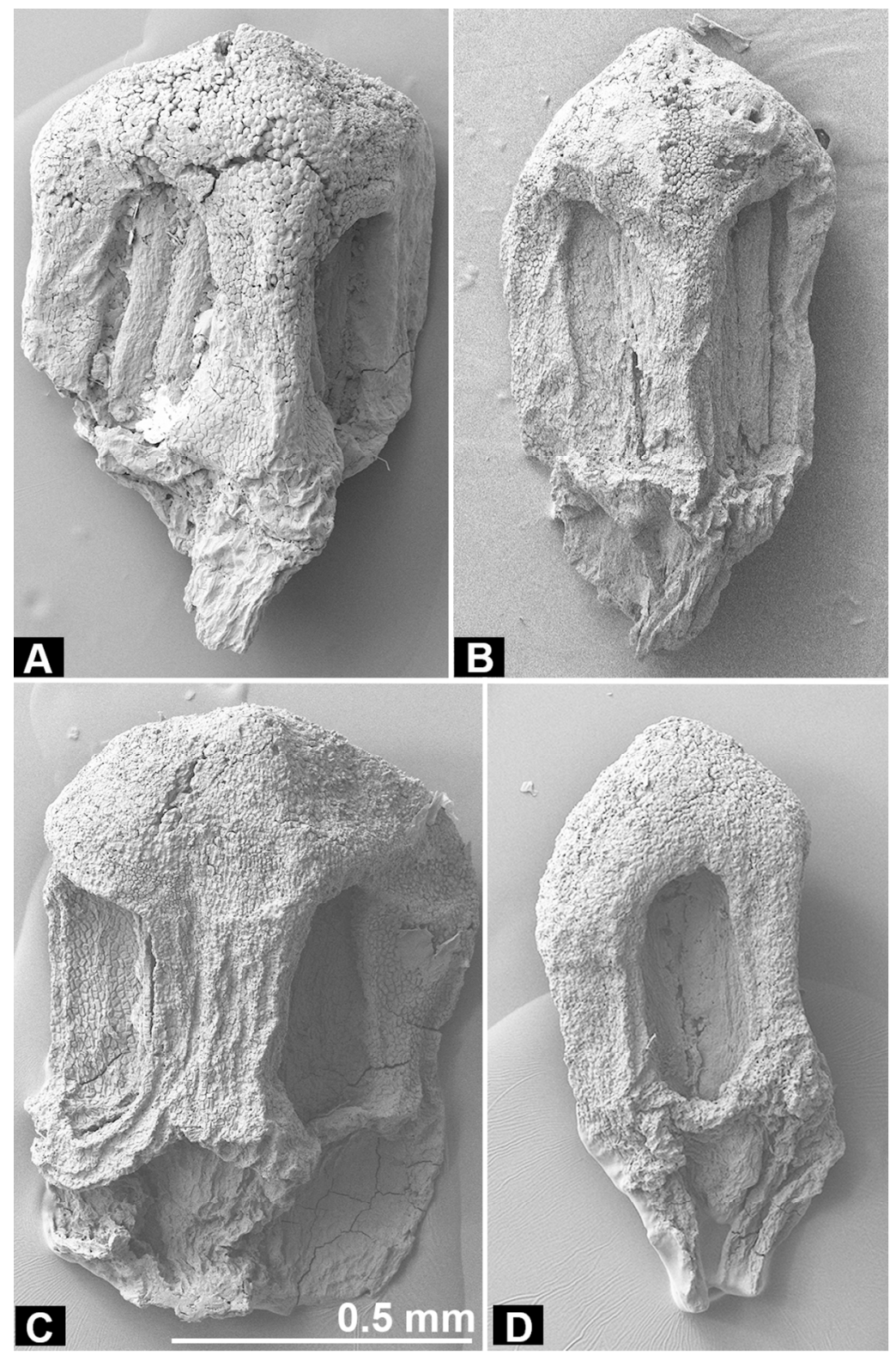

Figure 2. A-D. Dispersed stamens recovered from the same sample as the fossil flower specimen. A. Broken stamen with remnants of the outer theca wall suggestive of $\mathrm{H}$-valve dehiscence. Specimen PP55897. B. Stamen showing likely embedded pollen sacs. Tapering base is incomplete. Specimen PP55898. C. Stamen showing likely embedded pollen sacs. Base of specimen is incomplete. Specimen PP558999. D. Lateral view of stamen showing theca with outer wall missing. Specimen PP559000.

$91 \times 140 \mathrm{~mm}(300 \times 300 \mathrm{DPI})$ 

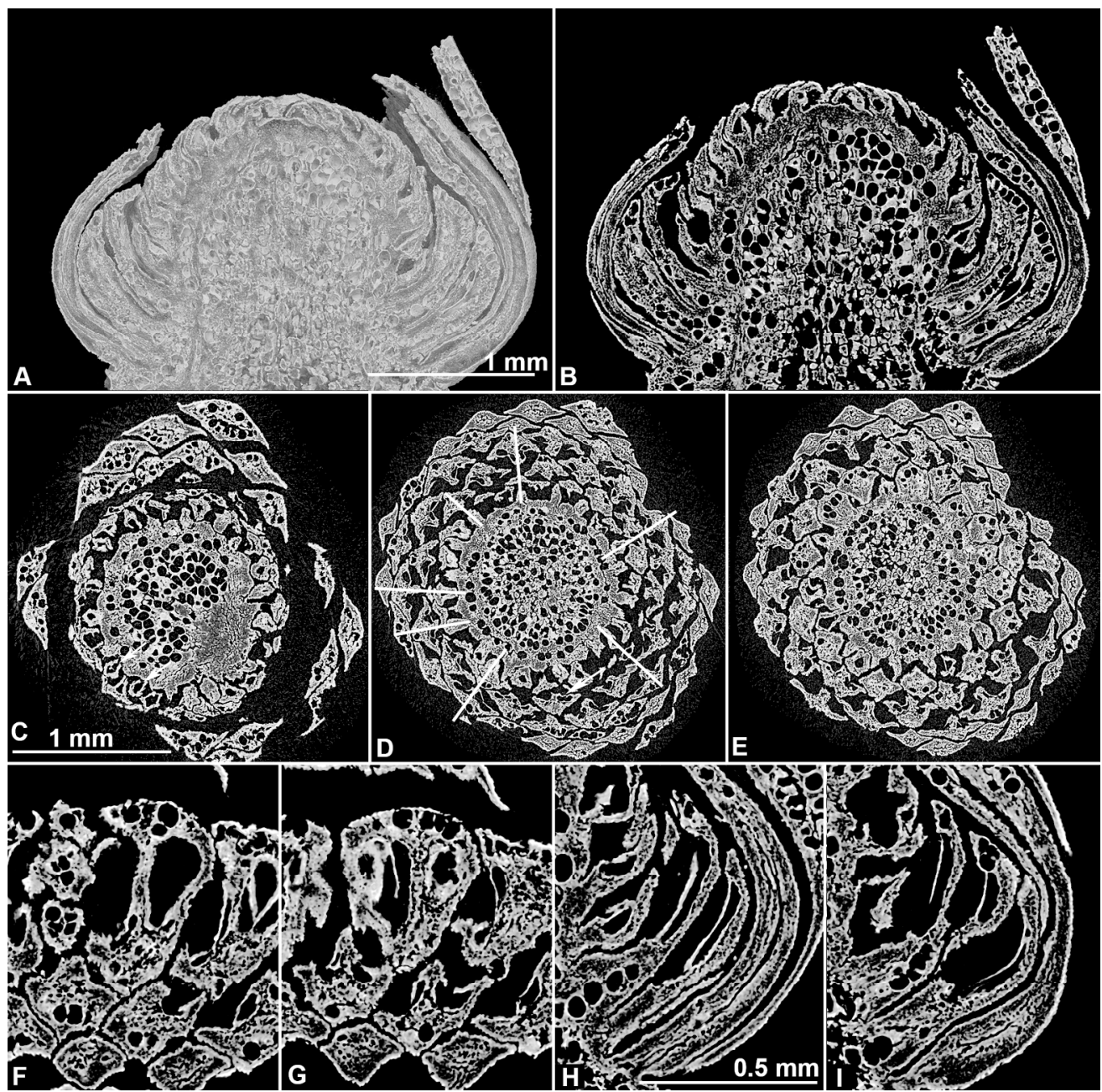

Figure 3. Synchrotron X-ray tomography renderings of fossil flower: longitudinal and transverse sections.

Specimen PP55896. A. Three dimensional rendering, median longitudinal section of flower. B. Two dimensional rendering, medial longitudinal section of flower. C-E. Transverse sections from near apex (C), center (D), and base (E). C. Transverse sections of several tepals are present. The spongy central receptacle is evident with attached carpels. Arrows indicate carpels showing a narrow gap in the ovary wall in the ventral median position. D. Section shows carpels attached to receptacle and transverse sections of spathulate stamens and tepals. Arrow indicates a stamen with embedded pollen sacs. Radiating lines indicate orthostichies in stamens and tepals. E. Section shows transverse views of spathulate stamens and tepals. F, G. Longitudinal sections of stamens showing pollen sacs. Incomplete wall between adjacent pollen sacs seen in G. H, I. Lateral longitudinal section of stamens showing embedded pollen sacs. $183 \times 182 \mathrm{~mm}(300 \times 300 \mathrm{DPI})$ 


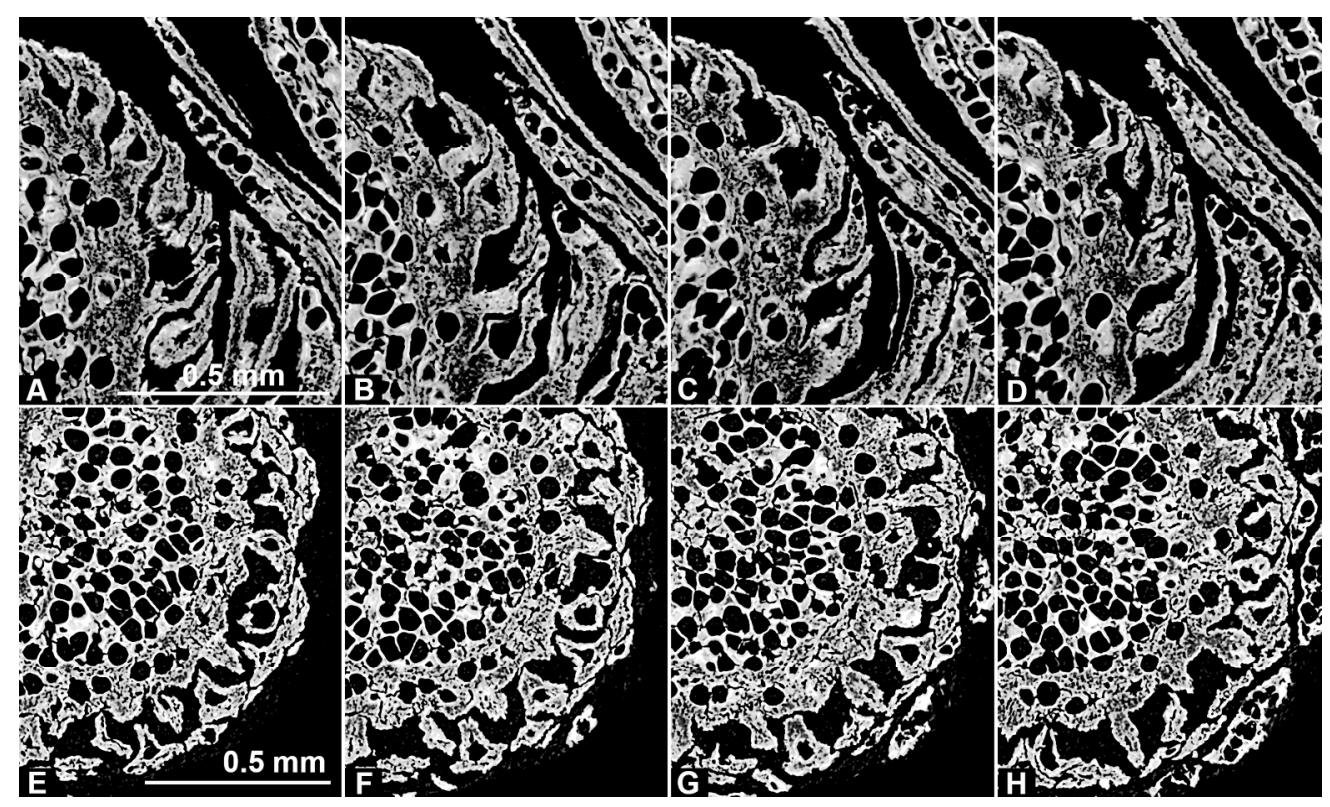

Figure 4. Synchrotron X-ray tomography renderings of fossil flower: longitudinal and transverse sections of carpels. Specimen PP55896. A-D. Longitudinal sections of carpels to show locule size and shape and apical projection of carpel beyond ovary. E-H. Transverse sections of carpels to show locule size and shape and narrow gap in the ovary wall in ventral median position. $183 \times 110 \mathrm{~mm}(300 \times 300 \mathrm{DPI})$ 

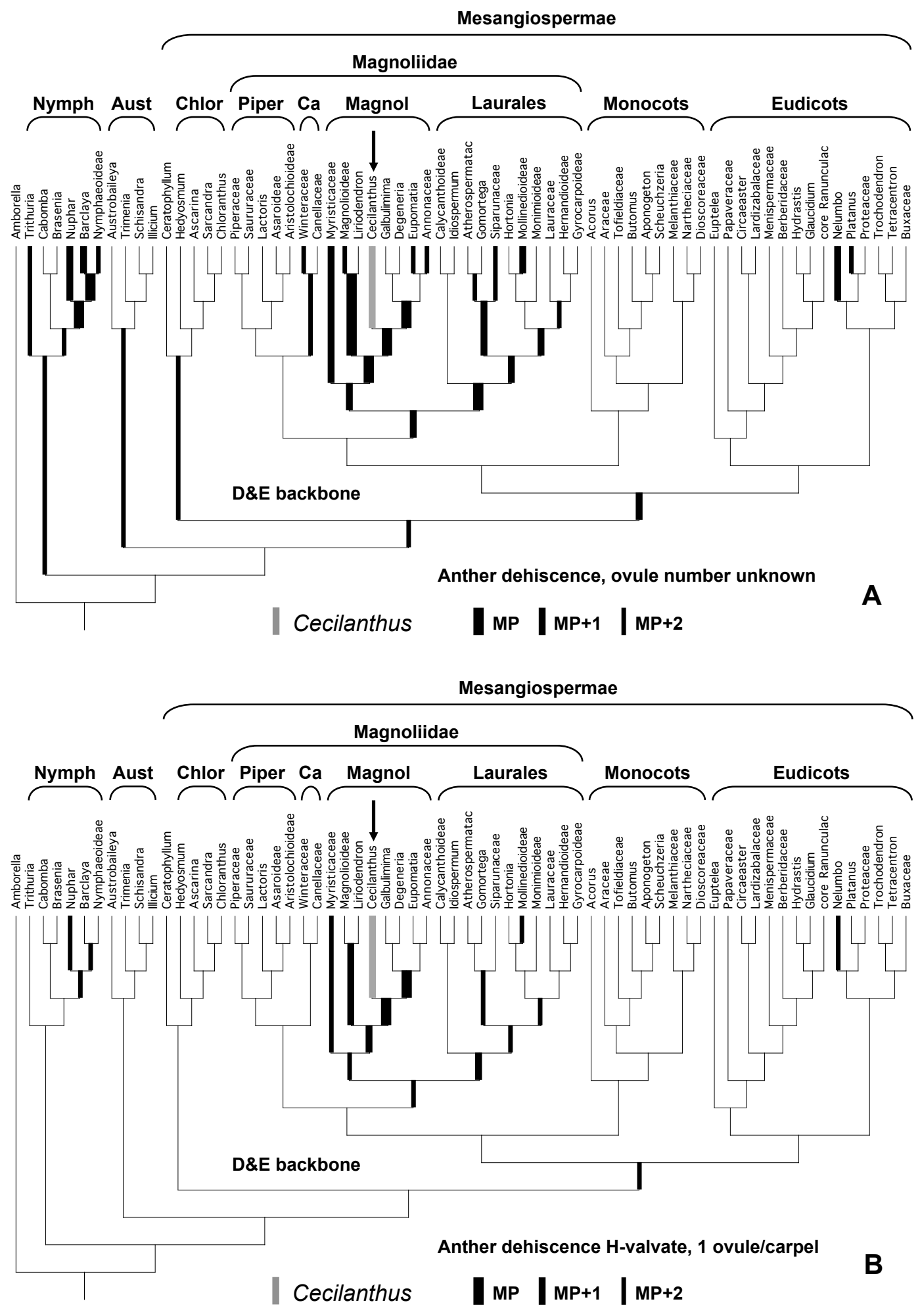

Fig. 5: D\&E backbone 
Page 47 of 50

Botany
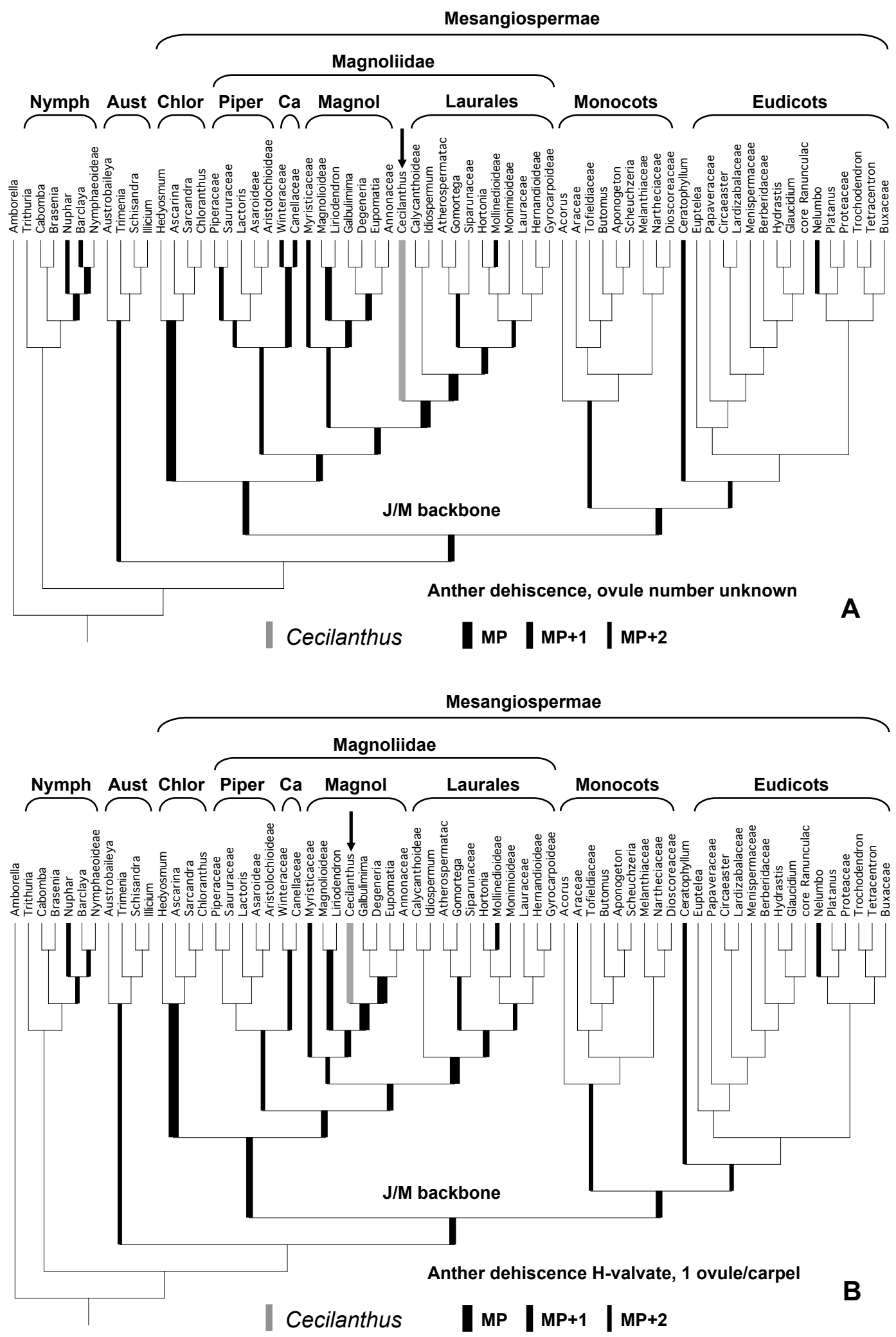

Fig. 6: J/M backbone

https://mc06.manuscriptcentral.com/botany-pubs 
Appendix A1. Characters in the Doyle and Endress (2014) matrix used in phylogenetic analyses, with states scored for Cecilanthus indicated in bold font. Uncertain scorings (e.g., 0/1) shown by indicating both states in bold font.

1-41. Vegetative characters: unknown.

42. Inflorescence (0) solitary flower (or occasionally with 1-2 lateral flowers), (1) botryoid, panicle, or thyrsoid (monotelic), (2) raceme, spike, or thyrse (polytelic): unknown.

43. Inflorescence partial units (0) single flowers, (1) cymes: unknown.

44. Inflorescence (or partial inflorescence) (0) not modified, (1) modified into globular head. Inferred from presence of a pedicel.

45. Pedicel (0) present in some or all flowers, (1) absent or highly reduced (flower sessile).

46. Floral subtending bracts (0) present, (1) present in female, absent in male flowers, (2) absent in all flowers: unknown.

47. Sex of flowers (0) bisexual, (1) unisexual.

48. Floral base (0) hypanthium absent, superior ovary, (1) hypanthium present, superior ovary, (2) partially or completely inferior ovary.

49. Floral receptacle (female portion) (0) short, (1) elongate.

50. Pits in receptacle bearing individual carpels (0) absent, (1) present.

51. Cortical vascular system (0) absent or supplying perianth only, (1) supplying androecium, (2) supplying androecium plus gynoecium: unknown.

52. Floral apex (0) used up after production of carpels, (1) protruding in mature flower.

53. Perianth (0) present, (1) absent.

54. Perianth phyllotaxis (0) spiral, (1) whorled. See text for discussion. 
55. Perianth merism (0) trimerous, (1) dimerous, (2) polymerous.

56. Perianth whorls (series when phyllotaxis is spiral; includes petals) (0) one, (1) two, (2) more than two.

57. Tepal differentiation (0) all more or less sepaloid; (1) outer sepaloid, inner distinctly petaloid; (2) all distinctly petaloid. Preserved tepals are markedly elongate and thus more petaloid than sepaloid, but the outermost tepals are represented only by scars and cannot be characterized.

58. Petals (0) absent, (1) present.

59. Nectaries on inner perianth parts (0) absent, (1) present: unknown.

60. Outermost perianth parts (0) free, (1) at least basally fused.

61. Calyptra derived from last one or two bracts below the flower (0) absent, (1) present.

62. Stamen number (0) more than one, (1) one.

63. Androecium phyllotaxis (0) spiral, (1) whorled. See text for discussion.

64. Androecium merism (0) trimerous, (1) dimerous, (2) polymerous.

65. Stamen whorls (series when phyllotaxis is spiral; includes inner staminodes) (0) one, (1) two,

\section{(2) more than two.}

66. Stamen positions (0) single, (1) double (at least in outer whorl).

67. Stamen fusion (0) free, (1) connate.

68. Inner staminodes (0) absent, (1) present. Innermost androecium members are similar to outer members in surface view and both longitudinal and transverse sections. A couple in the innermost cycle can be seen to have definite pollen sacs.

69. Glandular food bodies on stamens or staminodes (0) absent, (1) present. 
70. Stamen base (0) short (2/3 or less the length of anther), (1) long ( $>2 / 3$ length of anther) and wide ( $>1 / 2$ width of anther), (2) long ( $2 / 3$ or more length of anther) and narrow $(<1 / 2$ width of anther) (typical filament).

71. Paired basal stamen glands (0) absent, (1) present.

72. Connective apex (0) extended, (1) truncated or smoothly rounded, (2) peltate.

73. Pollen sacs (0) protruding, (1) embedded.

74. Microsporangia (0) four, (1) two. Partition is visible in many transverse sections.

75. Orientation of dehiscence (0) distinctly introrse, (1) latrorse to slightly introrse, (2) extrorse.

76. Mode of dehiscence (0) longitudinal slit, (1) H-valvate, (2) valvate with upward-opening flaps. Scored both as unknown and as H-valvate.

77-95. Stamen anatomy, microsporogenesis, and pollen characters: unknown.

96. Carpel number (0) one, (1) 2-5 in one whorl, (2) $>5$ in one whorl, (3) $>1$ whorl.

97. Carpel form (0) ascidiate, (1) intermediate, ovule(s) on ascidiate zone, (2) plicate. See text for discussion.

98-100. Postgenital sealing, secretion, and pollen tube transmitting tissue: unknown.

101. Style (0) absent (stigma sessile or capitate), (1) present (elongated, distinctly constricted apical portion of carpel).

102. Stigma (0) extended (half or more of the style-stigma zone), (1) restricted (above slit or around its upper part): unknown.

103. Multicellular stigmatic protuberances or undulations (0) absent, (1) present.

104-105. Stigmatic papillae, extragynoecial compitum: unknown.

106. Carpel fusion (0) apocarpous, (1) parasyncarpous, (2) eusyncarpous (at least basally).

107. Oil cells in carpels (0) absent or internal, (1) intrusive. 
108. Long unicellular hairs on and/or between carpels (0) absent, (1) present.

109-111. Short appressed hairs, carpel nectaries: unknown.

112. Number of ovules per carpel (0) one, (1) two or varying between one and two, (2) more than two. Scored both as unknown and as one.

113-142. Placentation, ovule morphology, fruit and seed characters: unknown. 